\begin{tabular}{|c|c|c|c|}
\hline$D E$ & \multirow{3}{*}{$\begin{array}{l}\text { DE GRUYTER } \\
\text { OPEN }\end{array}$} & $\begin{array}{l}\text { HUNGARIAN JOURNAL OF } \\
\text { INDUSTRY AND CHEMISTRY }\end{array}$ & \multirow[t]{3}{*}{$\begin{array}{l}\text { HUNAGARIAN JOURNALI OI } \\
\text { INIDUSTIRY ANID CIIIEMISTIRSY }\end{array}$} \\
\hline & & Vol. 43(1) pp. 15-18 (2015) & \\
\hline & & $\begin{array}{l}\text { hjic.mk.uni-pannon.hu } \\
\text { DOI: 10.1515/hjic-2015-0003 }\end{array}$ & \\
\hline
\end{tabular}

\title{
NITROGEN REMOVAL CONTROLLED BY AN AMMONIUM-ANALYSER AT THE NORTH PEST WASTEWATER TREATMENT PLANT
}

\author{
ZSÓFIA KASSAI \\ Budapest Sewage Works PTE Ltd., Asztalos Sándor u. 4., Budapest, 1087, HUNGARY
}

\begin{abstract}
At the North Pest Wastewater Treatment Plant, a nutrient removal process has been in operation since 2011. New tanks have been built, which can receive approximately half of the pre-settled wastewater. A predenitrification system has been planned and built both to the old and new lines. Due to the relatively small anoxic zones, periodic aeration was initiated first in the new line to achieve the lowest possible effluent total nitrogen concentration. Because of its positive impact, the operation of periodic aeration was initiated in the old line as well. Ammonium-analysers are used to control the aeration periods. Due to this process, the plant can provide a very low total nitrogen effluent value (below $10 \mathrm{mg} \mathrm{dm}^{-3}$ on average) as well as save energy and operational costs.
\end{abstract}

Keywords: wastewater treatment, nitrogen removal, nitrification, denitrification, ammoniumanalyser, operation control, periodic aeration

\section{Introduction}

In the North Pest Wastewater Treatment Plant, the nutrient removal phase has been in operation since 2011. The pre-settled wastewater is divided into two parts: one part is led to the " $\mathrm{A}$ " biological line and the other to the "B" line. Both biological lines were constructed for pre-denitrification with anoxic selectors. Since the volume of these selectors is relatively small, the operation of periodic aeration is carried out in order to provide more time for the denitrifying bacteria to use the slowly biodegradable particulate chemical oxygen demand (COD) as well.

The aim of its operation is to keep the effluent total nitrogen (TN) concentration under an annual average value of $10 \mathrm{mg} \mathrm{dm}^{-3}$. Therefore, the precise control of periodic aeration is important to fulfil this aim and save energy and costs as well.

\subsection{Nitrification and Denitrification}

In the case of municipal wastewaters, the hydrolysis of nitrogen containing compounds takes place mainly in the sewage system. Therefore, ammonium is the main form of nitrogen present in the influent wastewater. The nitrogen content of the filtration originates from the sludge treatment technology, which could also be significant for wastewater treatment plants.

The first step of the biological nitrogen removal process is nitrification, which is the biological oxidation of ammonia or ammonium to nitrite followed by the oxidation of the nitrite to nitrate. The process is performed by autotrophic bacteria as follows:

Correspondence: kassaizs@fcsm.hu

$$
\left[\mathrm{NH}_{4}\right]^{+}+\mathrm{O}_{2}+\mathrm{CO}_{2} \rightarrow\left(\mathrm{MO}_{\mathrm{A}}\right) \rightarrow\left(\mathrm{MO}_{\mathrm{A}}\right)^{\prime}+\mathrm{NO}_{\mathrm{x}}+2 \mathrm{H}^{+}
$$

where $\left(\mathrm{MO}_{\mathrm{A}}\right)$ and $\left(\mathrm{MO}_{\mathrm{A}}\right)^{\prime}$ stand for autotrophic bacteria.

The growth rate and specific sludge production of the nitrifying bacteria are lower than for heterotrophic bacteria, thus the growth of the autotrophic bacteria has to be in the appropriate ratio of wastewater quality to amount of sludge production [1, 2]. Therefore, appropriate sludge loading can balance out the conditions for the growth of the two groups of bacteria. Increasing the sludge retention time and decreasing the organic loading rate of the activated sludge could balance out the disadvantage posed by the nitrifying bacteria $[3,4]$.

The second step of nitrogen removal is denitrification, when special heterotrophic facultative anaerobic bacteria produce molecular nitrogen $\left(\mathrm{N}_{2}\right)$ from nitrate as follows:

$\mathrm{NO}_{\mathrm{x}}+\mathrm{BOD}_{5}+\mathrm{H}^{+} \rightarrow\left(\mathrm{MO}_{\mathrm{H}}\right) \rightarrow\left(\mathrm{MO}_{\mathrm{H}}\right)^{\prime}+\mathrm{N}_{2}+\mathrm{CO}_{2}$

where $\mathrm{BOD}_{5},\left(\mathrm{MO}_{\mathrm{H}}\right)$, and $\left(\mathrm{MO}_{\mathrm{H}}\right)$ ' stand for biological oxygen demand, and heterotrophic bacteria, respectively.

\section{Experimental Setup}

During the construction of the nutrient removal phase a pre-denitrification system was built both in the "A" and "B" lines with 2-2 ganged, rectangular, mixed anoxic reactors for each section. Both " $A$ " and " $B$ " lines have four parallel sections. In the case of the "A" line, the anoxic selectors were separated from the beginning of 


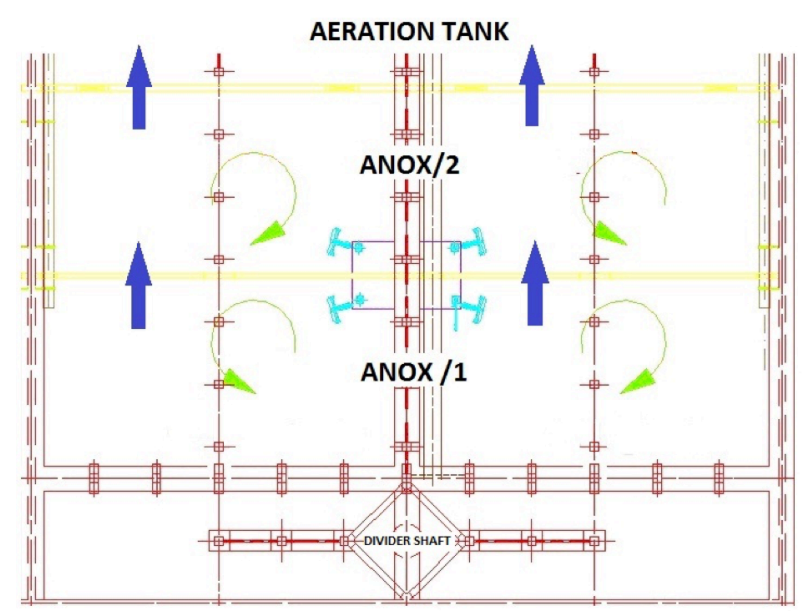

Figure 1. Schematic overview of anoxic selectors in the "A" line.

Table 1: Planned and real daily loads in $\mathrm{kg}$.

\begin{tabular}{crrrccc}
\hline \multirow{2}{*}{ Load } & planned & \multicolumn{2}{c}{ actual } & \multicolumn{2}{c}{ deviation in \% } \\
& & 2013 & \multicolumn{2}{c}{2014} & 2013 & 2014 \\
& annual & annual & $1^{\text {st }}$ quarter & annual & $1^{\text {st }}$ quarter \\
\hline COD & 133406 & 73103 & 74692 & 55 & 56 \\
BOD $_{5}$ & 72800 & 41390 & 42043 & 57 & 58 \\
TSS & 63336 & 41408 & 37316 & 65 & 59 \\
$\mathrm{NH}_{4}-\mathrm{N}$ & 7553 & 6298 & 6357 & 83 & 84 \\
TN & 11575 & 9137 & 9487 & 79 & 82 \\
TP & 1984 & 1164 & 1279 & 59 & 65 \\
\hline
\end{tabular}

Loads: $\mathrm{COD}=$ chemical oxygen demand, $\mathrm{BOD}_{5}=$ biological oxygen demand, TSS $=$ total suspended solids, $\mathrm{NH}_{4}-\mathrm{N}=$ ammonium nitrogen, $\mathrm{TN}=$ total nitrogen, $\mathrm{TP}=$ total phosphorous

the existing rectangular aeration tanks (Fig.1). As for the "B" line, the new anoxic reactors were built before the new Caroussel type aeration tanks (Fig.2). The volume of the anoxic tanks is relatively small, since only 18 vol.\% of the total activated sludge can be held in both lines.

The best available effluent total nitrogen value was chosen for the design of the control system of the nitrogen removal program instead of the smallest ammonium nitrogen value. The standard value for total nitrogen is $35 \mathrm{mg} \mathrm{dm}^{-3}$, but the aim of the plant was to keep the effluent total nitrogen under $10 \mathrm{mg} \mathrm{dm}^{-3}$ as an annual average. The problem was that for the small anoxic volumes there was not enough time for the denitrification to take place completely. The other challenge was that the quality of the incoming wastewater had changed, since the original design of the nutrient removal phase was made. The incoming wastewater was diluted, but the rate of dilution was not the same for each parameter (Table 1).

\section{Results and Analysis}

The organic matter content $\left(\mathrm{COD}, \mathrm{BOD}_{5}\right)$ and the total suspended solids (TSS) decreased the most, while the decrease in nutrients, especially in the nitrogen forms was only modest. The difference was caused by the filtration water of the sludge dewatering system (Table 2). At the wastewater treatment plant, there are two

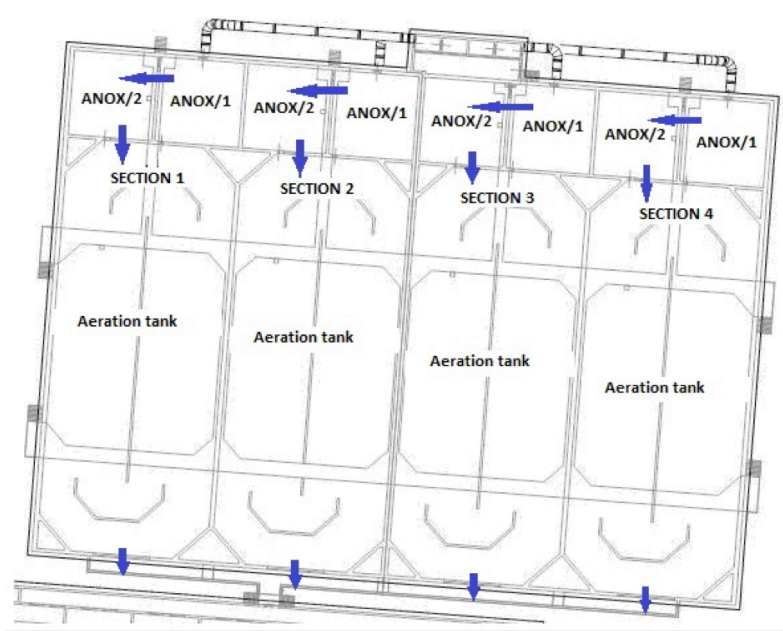

Figure 2. Schematic layout of the "B" line.

Table 2. Average COD and nitrogen content of the filtration water in $\mathrm{mg} \mathrm{dm}^{-3}$.

\begin{tabular}{ccccc}
\hline & $\mathrm{COD}$ & $\begin{array}{c}\mathrm{N} \\
\left(\mathrm{NH}_{3}-\mathrm{NH}_{4}\right)\end{array}$ & $\mathrm{TN}$ & $\begin{array}{c}\mathrm{COD}: \mathrm{TN} \\
\text { ratio }\end{array}$ \\
\hline 2013 & 847 & 1,163 & 1,326 & $\sim 1: 1.6$ \\
$\begin{array}{c}20141 \mathrm{st} \\
\text { quarter }\end{array}$ & 815 & 1,091 & 1,262 & $\sim 1: 1.5$ \\
\hline
\end{tabular}

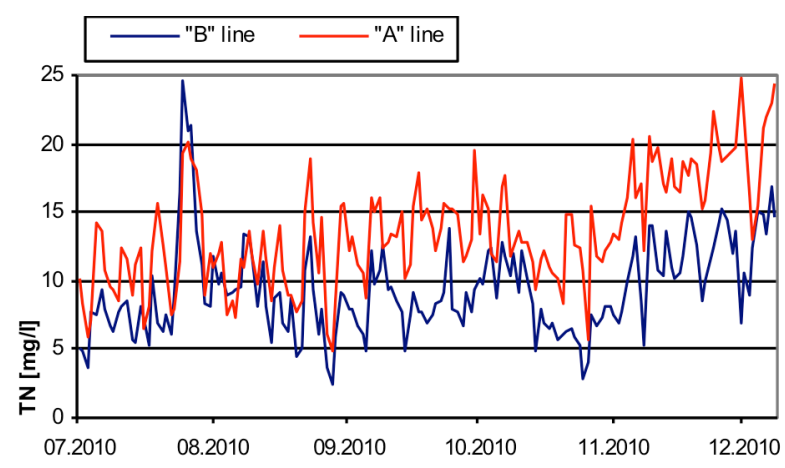

Figure 3. Effluent total nitrogen values between July and December 2010.

operating mesophilic digesters with a volume of 12,000 $\mathrm{m}^{3}$ each. These digesters receive not only the thickened sludge from the plant, but other wastes containing high quantities of organic matter, such as dried sludge, industrial wastewater, and animal protein. In Table 2 , it can be seen that the nitrogen content of the filtration is very high so the ratio of the nitrogen in the influent wastewater is higher, too.

Considering the planned values from Table 1, the COD:TN ratio is $11.5: 1$ while the actual ratio is only $7-$ 8:1. Previous experiments showed that the readily biodegradable soluble COD $\left(\mathrm{S}_{\mathrm{S}}\right)$ content of the wastewater is only about $20 \%$ [5], thus the total amount of organic matter isn't available for the denitrifying bacteria in the anoxic zones. The average hydraulic retention time in the anoxic zones is about 3.5 hours. With periodic aeration (Fig.3), the denitrifying bacteria can consume not only the $S_{S}$, but the slowly biodegradable particulate COD, which becomes available as a result of hydrolysis. 
Table 3. Control parameters for aeration in the " $\mathrm{B}$ " line.

\begin{tabular}{ccc}
\hline $\begin{array}{c}\mathrm{NH}_{4}-\mathrm{N} \text { level } \\
\left(\mathrm{mg} \mathrm{dm}^{-3}\right)\end{array}$ & $\begin{array}{c}\text { Sections with } \\
\text { aeration on } \\
{[\mathrm{pcs}]}\end{array}$ & $\begin{array}{c}\text { Sections with } \\
\text { aeration off } \\
{[\mathrm{pcs}]}\end{array}$ \\
\hline$<5.0$ & 1 & 3 \\
$5.0-7.0$ & 2 & 2 \\
$7.0-10.0$ & 3 & 1 \\
$>10.0$ & 4 & 0 \\
\hline
\end{tabular}

Table 4. Average effluent values in $\mathrm{mg} \mathrm{dm}^{-3}$ between January and August 2014

\begin{tabular}{ccc}
\hline Load & Effluent & Standard \\
\hline COD & 30 & 125 \\
BOD $_{5}$ & $<10$ & 25 \\
TSS & 5 & 35 \\
$\mathrm{NH}_{4}-\mathrm{N}$ & 2.54 & 10 \\
$\mathrm{TN}$ & 9.63 & 35 \\
$\mathrm{TP}$ & 1.39 & 5
\end{tabular}

Loads: $\mathrm{COD}=$ chemical oxygen demand, $\mathrm{BOD}_{5}=$ biological oxygen demand, $\mathrm{TSS}=$ total suspended solids, $\mathrm{NH}_{4}-\mathrm{N}=$ ammonium nitrogen, $\mathrm{TN}=$ total nitrogen, $\mathrm{TP}=$ total phosphorous

First, the periodic aeration system was evaluated in the "B" line as shown in Fig.3. The blue diagram shows the effluent total nitrogen values from the " $B$ " line, the red from the " $\mathrm{A}$ " line. It can be seen that with periodic aeration the effluent values from the " $B$ " line are much lower compared to the " $\mathrm{A}$ " line. Due to this positive effect, the periodic aeration process has been used in the "A" line since 2011 as well.

\subsection{Controlling Periodic Aeration}

In the case of the " $\mathrm{B}$ " line, controlling the system is quite simple, because the treated wastewater coming from four parallel, activated sludge tanks is mixed before the final settling tanks. There is a short channel before the wastewater is divided and led to the eight rectangular secondary sedimentation tanks, where a 'Hach Lange AMTAX sc.'-type ammonium-analyser is set up. Aeration is controlled by the measured ammonium-nitrogen value (Table 3). Due to the Carousel race-track type activated sludge tanks, aeration can be switched off even for 3 hours, because the four agitators in each section do not let the sludge settle.

Controlling the "A" line was much more difficult partly because there are no agitators in the rectangular activated sludge tanks. On the other hand, the wastewater coming from four sections is only mixed after the final settling. Thus, the ammonium-nitrogen level has to be measured separately for each section.

There are two 'AMTAX sc.'-type ammoniumanalysers in dual channel mode for the " $A$ " line for Sections 1-2 and separately for Sections 3-4. Because of the lack of agitators, there is a time limit in order to prevent the sludge from settling. After 60 minutes, the aeration has to be switched on even if the measured ammonium is not over the set value.

In the " $A$ " line, all the sections are controlled separately. The hours when aeration is switched on and

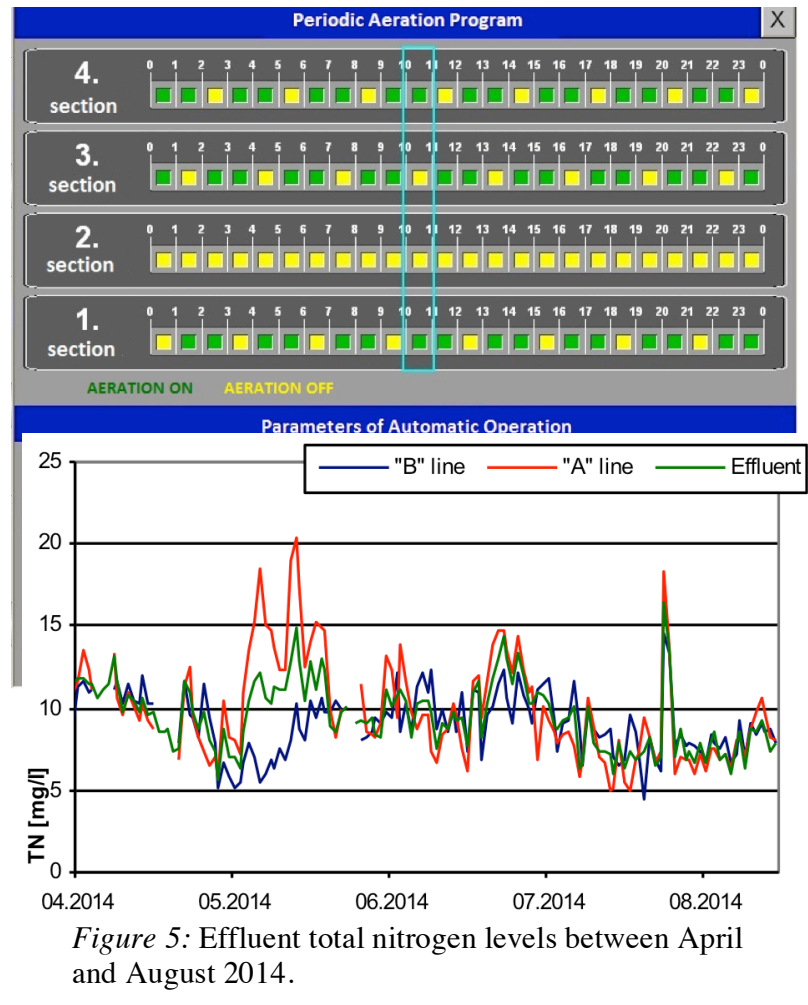

off can be chosen. There are "manual", "time control", and "automatic" modes as shown in Fig.4. In "time control" mode the operator can fill in a timetable with aeration periods (green). Yellow areas show the hours when the aeration is turned off.

In "automatic" mode, the program calculates an average $\mathrm{NH}_{4}-\mathrm{N}$ for each section from the past hour and compares it to the set values. If the average value is under the minimum in a section then there will be two hours with aeration on and one hour off (Fig.4). If the value is between the limits, there will be three aeration hours and one without. If the average value is over the maximum limit, aeration remains on until the value decreases below the limit. The operation of the blowers is also an important parameter. Aeration must not be switched off in every section at once.

Fig. 5 shows the effluent total nitrogen levels for the controlled periodic aeration of both lines. In May, the "A" line operated under "time control", thus the effluent results were much better in the "B" line. Automatic control of the "A" line was turned on in the summer of 2014 as shown in Fig.5. Sometimes the effluent values in the "A" line are better according to the TN than in the "B" line as can be seen from data point 06.2014. Due to periodic aeration, the effluent total nitrogen level was under the annual average of $10 \mathrm{mg} \mathrm{dm}^{-3}$ (Table 4).

\section{Conclusion}

Our study indicates that with periodic aeration external carbon sources are not needed at the North Pest Wastewater Treatment Plant in order to ensure the requested total nitrogen value. For optimal operation, control by ammonium analysers is essential, while the time-controlled system did not prove to be sufficient. 


\section{Acknowledgement}

This work was supported by the staff of the North Pest Wastewater Treatment Plant and the Laboratory of Budapest Sewage Works Ltd.

\section{REFERENCES}

[1] Kárpáti, Á.: Ways of development in activated sludge systems - I. BOD and nitrogen removal. 1-14. II. Biological phosphorous removal and optimal utilization of organic carbon sources. 1424. In Activated sludge systems and control. No. 2. Ed.: Kárpáti, Á. (University of Veszprém, Department of Environmental Engineering and Chemical Technology, Veszprém, Hungary) 2002, pp. 97 (in Hungarian)
[2] Kárpáti, Á.; Pásztor, I.; Pulai, J.: Current and future perspectives of nitrogen removal in wastewater treatment, VÍZMÚ Panoráma, 2004 7(2) 17-22 (in Hungarian)

[3] Grady, L.C.P.; Lim, H.C.: Biological wastewater treatment. Theory and applications (Marcel Dekker, New York, USA) 1980

[4] Henze, M.; Gujer, W.; Mino, T.; Matsuo, T.; Wentzel, M.C.; Marais, G.v.R.: Activated sludge model No. 2. (IAWQ Scientific and Technical Report, London, UK) 1995

[5] Kassai, Zs.: Modeling processes undergoing under anoxic conditions with NUR test, Proc. MHT Meeting, Sopron, Hungary, pp. 1-7 2010 (in Hungarian) 